\title{
WHY MUST I CRY? JUSTIFICATION, SACRIFICE, LONELINESS, MADNESS AND LAUGHTER IN POST- APARTHEID JUDICIAL DECISION-MAKING
}

\author{
by Michael Bishop*
}

\author{
Why must I cry \\ these tears from my eyes? \\ Why must I cry \\ these tears from my eyes? \\ Why must I trod \\ this lonely, lonely, lonely road? \\ Why must I carry \\ this heavy, big heavy, big heavy load? \\ Why must I cry \\ these tears from my eyes? \\ Why must I cry \\ these tears from my eyes? \\ Why must I trod? ${ }^{1}$
}

Introduction

Peter Tosh's plaintive - 'Why must I cry?' - is normally interpreted to be about a lost lover. It probably is. But I am going to propose a different reading. I am going to pretend that Peter Tosh is a conscientious South African judge with postmodernist and critical legal tendencies. This judge is concerned with the massive responsibility she feels as a judge in post-apartheid South Africa. Not only must she walk the lonely, lonely, lonely road of ordinary judicial office, she must bear the big heavy load of the specific social, economic and political circumstances that place added pressure on her to transform, both society and herself.

* $\quad$ BA LLB LLM (Pret), junior researcher at the South African Institute for Advanced Constitutional, Public, Human Rights and International Law (SAIFAC) and extraordinary lecturer, Faculty of Law, University of Pretoria.

$1 \quad$ Peter Tosh 'Why must I cry?' from the album Legalise it (1976). 
At the same time, she is confronted with critical theories that seek to impose an even greater burden on her in the form of unanswerable calls to justice and unfulfillable duties to the other. These theories are, on the whole, framed in a way that is both critical of judges and largely pessimistic about the possibility of success. Many of the theories specifically require the judge to mourn her inability to do the impossible. For many reasons then, our hypothetical judge asks: 'Why must I cry?' My answer in brief is: She need not cry. She must not cry. I will argue that the best means to address the various responsibilities imposed on judicial officers is through laughter, not tears.

I begin by detailing the 'culture of justification' that dominates both judicial and academic thinking (I will look specifically at Mureinik, Klare and Botha) and examine exactly what burdens this philosophy imposes on judges. Next I acknowledge that the burdens of justification, onerous as they may be, are not enough. I adopt Van der Walt's ideal of 'law as sacrifice' to argue that all judges have the additional duty to acknowledge the sacrifices that are an inescapable part their profession.

Having heaped all these duties on judges, I acknowledge that all this responsibility must make them rather lonely. The paintings of Edward Hopper serve as both a reflection of this loneliness and a possible cure. In his paintings there dwells both a sadness and a joy a joy that I hope can be shared by judges and that may, sometimes, enable them to acknowledge sacrifice.

But even with our altered concept of loneliness developed through the suppressed beauty of Hopper's art, judges must, if they take their work seriously at all, go a little crazy with the weight of their unbearable burden. That leads me to the idea of madness, specifically Derrida's notion of madness as the moment of decision. This brush with Derrida forces us to consider whether there is a way, even if sacrifice is acknowledged, to achieve just decisions.

I conclude by looking at humour and the law. Humour in judicial decisions has played an often unnoticed role (more in America than South Africa!) in the law reports, but it is one that I think should be encouraged. Uses of humour by other facets of the legal profession should also be encouraged for the way it confronts the law and lawyers with their own failures and weaknesses. But the most important role of humour is to facilitate the madness that Derrida requires for justice. In the madness of laughter there is the space for the trace of justice and the ghost of plurality born of the acknowledgment of sacrifice. Laughter cannot ensure justice, but it can make it easier to attain and easier to lose.

If I can laugh - why must I cry? 
Justification permeates all corners of our post-apartheid legal order. Possibly the most far-reaching endorsement for justification is the limitations clause. While the Bill of Rights guarantees more extensive protection of human rights than any other constitution in the world, any one of those rights can be limited by section 36 if the limitation is 'reasonable and justifiable in an open and democratic society based on human dignity, equality and freedom'. ${ }^{2}$ But a section 36 analysis is only the beginning of the way in which justification has been woven into the fabric of our constitutional jurisprudence.

At the dawn of the new constitutional era, Mureinik wrote a highly influential article in which he engaged with the reference in the postamble of the interim Constitution ${ }^{3}$ to a bridge. ${ }^{4}$ Mureinik argued that apartheid society had been characterised by a culture of authority, where unjust laws were enforced not because of their content, but because of the power wielded by those who made them. ${ }^{5}$ If that was the apartheid past, it was clear to Mureinik what the postapartheid future should hold: the bridge of the Constitution 'must lead to a culture of justification - a culture in which every exercise of power is expected to be justified; in which the leadership given by government rests on the cogency of the case offered in defence of its decisions, not the fear inspired by the force at its command. ${ }^{6}$ This 'culture of justification' has been embraced by the courts as supporting the proposition that power can no longer be exercised arbitrarily but must be rationally related to a legitimate government purpose.

2 Constitution of the Republic of South Africa 1996 (Constitution) sec 36.

3 Constitution of the Republic of South Africa Act 200 of 1993 (interim Constitution).

4 E Mureinik 'A bridge to where? Introducing the interim Bill of Rights' (1994) 10 South African Journal on Human Rights 31.

5 Mureinik (n 4 above) 32. This culture was also 'an indispensable nursery for the feature of apartheid that most people would consider its defining characteristic: the reduction of law to racial discrimination - differentiation on the ground of race that is not justified. Without a culture of authority it is difficult to imagine how its gardeners would have cultivated the forest of apartheid statues whose most distinctive feature was their want of justification' (footnote omitted).

$6 \mathrm{n} 5$ above. This linear conception of the bridge metaphor has been criticised in more recent times. See eg A van der Walt 'Dancing with codes - Protecting, developing and deconstructing property rights in a constitutional state' (2001) 118 South African Law Journal 258 296, who argues for a bridge that 'allows and invites multiple crossings, in both directions' that denies an ending to transformation or interpretation and leaves room to 'imagine alternative futures'; W le Roux 'Bridges, clearings and labyrinths: The architectural framing of post-apartheid constitutionalism' (2004) 19 South African Public Law 629 640642 , who examines various concepts of the bridge and advocates a bridge that takes limits of imagination as its starting point.

7 See Prinsloo $v$ Van der Linde \& Another 19973 SA 1012 (CC) para 25; Pharmaceutical Manufacturers Association of SA \& Another: In re Ex parte President of the Republic of South Africa \& Others 20002 SA 674 (CC) para 85. 
But this culture of justification impacts the courts far more directly. Klare was the first to argue that post-apartheid South Africa and Mureinik's culture of justification demand a transformative constitutionalism. ${ }^{8}$ This transformative constitutionalism has two aspects - a commitment to social change and a shift in legal culture both of which impact on the responsibility of judges. Under the first leg, judges are mandated, through their decisions, always to seek out the best way to forward the achievement of social equality. ${ }^{9}$ More importantly for present purposes, under the second leg, judges must acknowledge the limits of legal constraint. The new transformative culture demands that judges accept the role they already play in shaping the meaning of legal texts and acknowledge and take responsibility for the choices they make. Judges can no longer hide behind 'ordinary meanings' or 'established precedents' - they must be honest and candid, with us and with themselves, about how they reached their decisions. ${ }^{10}$

Botha explores in slightly more depth just how judges understand the notion of constraint to which Klare refers and how this affects their perception of their duty to be candid. ${ }^{11}$ Botha offers three metaphors to explain judicial constraint based on the work of Duncan Kennedy. The first metaphor represents the traditional legal thinking that 'constraint is a function of the objective properties of legal materials'. ${ }^{12}$ The judge is trapped in a forest where the trees are the constraints of legal precedent. The adventurous judge searching for justification in this forest cannot avoid or cut down the trees and only experiences freedom if he happens to reach a clearing that has not yet been 'cultivated by precedent'. 13

The second metaphor portrays legal argument as the 'play of argument bites'. Each side of a legal dispute has a number of accepted argument-bites that they can employ. However, for each bite there is a counter-bite that their opponent can employ that cancels out the original bite. ${ }^{14}$ For example, an applicant in a socioeconomic rights case might argue that the court must order the government to take immediate action as she needs effective relief. This would be met by the counter-bite that the court should respect

K Klare 'Legal culture and transformative constitutionalism' (1998) 14 South African Journal on Human Rights 146.

9 Klare (n 8 above) 150 ('Transformative constitutionalism connotes an enterprise of inducing large-scale social change through political processes grounded in law').

10 Klare (n 8 above) 164. ('[T]he legal profession needs to be more candid with itself and with the community at large about the politics of adjudication and to accept more forthrightly our responsibility (however limited and partial) for constructing the social order through adjudicative practices').

11 H Botha 'Freedom and constraint in constitutional adjudication' (2004) 20 South African Journal on Human Rights 249.

12 n 11 above.

13 n 11 above, 255.

14 n 11 above, 256-257. 
the separation of powers and not unduly interfere in the domain of the legislature or executive. Judges are constrained because they must phrase their argument in terms of the predetermined bites. This is ultimately a very cynical view as judges are left with a 'free' but uncontestable choice between the two sides. Judges still do not have to take responsibility for their judgments.

The final metaphor is of law as a field of action. In this metaphor the law is a field with visible boundaries that represent legal rules. Legal results fall either within or outside the field of legal activity. However, the judge can manipulate the field by shifting the boundaries or re-characterising or reworking arguments so that results fall on different sides of the boundary. The judge is free and constrained at the same time - the law constrains him as he cannot ignore it, but he can (often) overcome that constraint if he is willing to apply the necessary effort to the legal materials. ${ }^{15}$

This metaphor forces judges to take full responsibility for their decisions as they alone choose how far they are willing to go to achieve a particular outcome. Only in rare cases will they be absolutely unable to achieve the result they deem just so the outcome of the case is placed principally in the hands of the judge, not the objective hands of the legal system. The judge can no longer avoid the yoke of her decision. She must provide a full and acceptable justification for her decision. Anything less fails to live up to the ideal of the 'culture of candour' that has become an essential part of postapartheid judicial decision-making.

\section{Sacrifice}

Human nature is such

That incompletion is all

That remains with us. ${ }^{16}$

However, even this substantial responsibility is not the final layer of the massive burden that judges must bear. No matter how honest, how complete, how 'just' a judge's reasons, there is, in reality, no such thing as justification. According to Van der Walt ${ }^{17}$

every judicial decision is an inevitable representation of the law in a particular case, the inevitable representation that reduces to oneness the multiple conflicting desires and concerns that inform the law in a contradictory fashion.

The reduction inherent in every judicial decision demands the economic sacrifice of one of the litigants. This 'economic' sacrifice

$17 \mathrm{~J}$ van der Walt Law and sacrifice (2005) 11. 
does not refer to the loss of money or property. What is at issue here is the destruction of the litigant's honest expectations that his legal claim is right. If a litigant loses a case, he is told that the legal claim that he made is not reasonable and fails to conform to society's accepted law or morality. In order to remain a part of the community and a subject of the law, he must abandon his belief in his cause on the altar of the law where it will be sacrificed to the Gods of reason. The sacrificial lamb must choose between the acceptance of his violation or banishment from the political community: a rock and a hard place. ${ }^{18}$

This sacrifice is unavoidable and unjustifiable: 'The invocation of just grounds to justify sacrifice would effect but another failure or refusal to acknowledge sacrifice'. ${ }^{19}$ No extent of balancing or judicial candour can save the judge from sacrifice. A judge must perform the sacrifice; his only choice is which party comes under the knife. The only possibility open to the judge is to acknowledge the sacrifice of his decision. Through the acceptance that a litigant is 23 rificed and that this is unalterably unjustifiable, but must occur nonetheless, the 'trace of plurality', the 'trace of justice' is created. Indeed, as Van der Walt notes, plurality can exist only as a trace, a ghost, but more importantly, 'the decision itself [is] a trace of what is always left or being left behind. ${ }^{20}$ In essence then, it is only through the acknowledgment of the sacrificial character of law that plurality (as trace) can exist. 21

While this realisation offers hope to us all for the validity and ultimate 'justice' (as trace) of law as an ideal, it offers little solace to the judge. The judge must still sacrifice. Acknowledgment may permit plurality, but it does not prevent the sacrifice from taking place. The judge retains the unbearable burden of the unjustifiable sacrifice of one of the litigants. The judge must bear the burden alone. There is no help, no recourse to principle or precedent. No recourse to justice. It is a terribly lonely decision.

J van der Walt 'Law as sacrifice' (2001) Journal for South African Law 711. ('On top of having his honest expectations frustrated by a judicial decision, that person is also deprived of his honest expectations. He is told to let go of them. They are simply wrong ... To the extent that the person is not prepared to see reason, he simply does not share in the good morals of society').

19 See Van der Walt (n 17 above) 14. See also Van der Walt (n 18 above) 711 ('Judicial reasoning should not ratify this banishing effect by evoking a rhetoric of justice').

20 Van der Walt (n 17 above) 12.

21 Van der Walt argues that law and sacrifice are so intimately interwoven that not only must law be described in terms of sacrifice, sacrifice exists as the first instance of law (n 17 above, 132). 
Making decisions is all we as judicial officers have to offer. Each one should be as legally correct, fair and equitable as possible. One decision sticks out in my mind. For some reason it did not at the time feel that it fit on the easy-hard continuum. The only adjective that really seems to fit is 'lonely.' It just felt lonely. ${ }^{22}$

Judge Smith wrote this passage to describe a decision he had to make regarding a mentally disturbed man, one 'Mr Mitchell'. ${ }^{23}$ Mitchell had stopped taking his medication and as a result had severely assaulted his father. He was charged with both misdemeanours and felonies. His public defender argued that the felonies should be reduced to misdemeanours as this would allow him to receive appropriate psychiatric care. His father supported the proposal as he believed that his son could lead a perfectly stable life with the correct treatment. However, the law stated very clearly that a felony should only be reduced if the actions could in fact be characterised as the less serious 'misdemeanour' which the assault clearly could not. Smith (if he had been in post-apartheid South Africa) was obliged to justify his decision, constrained by legal precedent, and compelled to sacrifice either Mitchell or the public's interest in consistent law enforcement. It is easy to understand why he felt lonely. ${ }^{24}$

It is not only the 'hard cases' that are lonely; judges are always alone as they always bear the final responsibility for their decisions. Judges often talk about the loneliness of their office. In S v Malgas, the Supreme Court of Appeal, while interpreting minimum sentence legislation, noted that "[s]entencing has rightly been described as "a lonely and onerous task". 25 The old Appellate Division has described the 'application of modern western standards' to customary beliefs as a 'lonely and at times frighteningly difficult task' of the trial judge. ${ }^{26}$ A former clerk of US Supreme Court Justice Harlan wrote of him after his death that '[o]n Friday afternoons when he returned to chambers from the court conference and reported the votes, I thought I

Judge Smith ultimately refused to reduce the charge. Although he was moved by the particular circumstances of the case, he maintained faith that ultimately justice would be better served by maintaining the internal consistency of the legal system. 'It is important to understand that this decision was not just an act of elevating process over result. It was also an act of faith: faith that adhering to the law - following the appropriate process - would best serve the interests of all involved. It was an act of faith that treating the defendant's conduct for what it was in fact would trigger the appropriate responses of penal institutions, mental health services and other public and private agencies which would respond to $\mathrm{Mr}$ Mitchell's conduct and his condition' (n 22 above, 13).

2520012 SA 1222 (SCA) para 1 quoting J Hogarth Sentencing as a human process (1971) 5 .

26 S v Mkhonza 19811 SA 959 (A) 963F. The case concerned whether a family feud that mandated a killing reduced the moral blameworthiness of the accused. 
sometimes caught a hint of resignation to the loneliness of his position'. ${ }^{27}$ A similar sentiment was expressed about Justice Jackson who at one stage in his career slipped into 'a sad, silent, ineffectual loneliness of dissent'.28

This judicial loneliness finds possibly its most powerful portrayal in the paintings of the renowned American artist Edward Hopper. As Proulx notes, '[a]lmost every critic, artist, writer (especially writers), art savant, book-jacket designer or media hack sees in Hopper's mature paintings solitude, alienation, loneliness, psychological tension'. ${ }^{29}$ The subject of Hopper's art is the main source of this alienation. Hotels, diners, gas stations, lighthouses and trains are the focus, but also the backdrop for isolated, introspective figures who ${ }^{30}$

look as though they are far from home, they stand reading a letter on the edge of a hotel bed or drinking in a bar, they gaze out of the window of a moving train or read a book in a hotel lobby. Their faces are vulnerable and introspective. They have perhaps just left someone or been left, they are in search of work, sex or company, adrift in transient places. It is often night and through the window lie the darkness and threat of the open country or of a strange city.

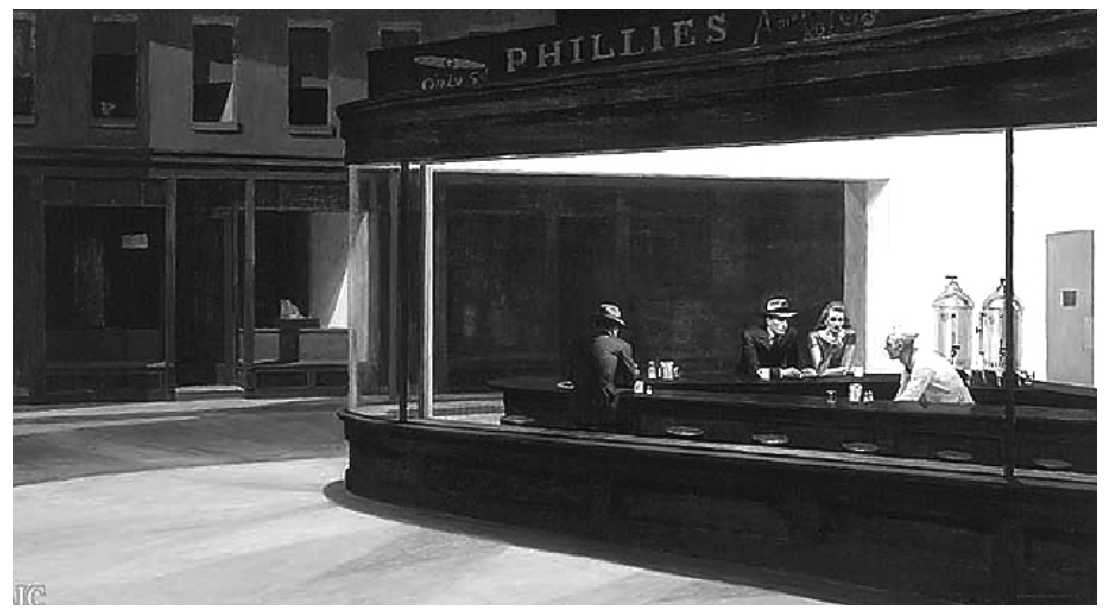

For example, in Nighthawks Hopper's focus is a diner, late at night, in what seems to be a large American city. A barman is pouring a drink while staring vacantly out of the large window that encircles the whole scene. There is a couple facing us. The woman looks absently at her fingernails and seems lost in thought, hardly noticing 
the man at her side. Her partner seems resigned and is carelessly observing the barman pouring his drink. They are not looking at each other and although they are physically close, their minds are worlds apart. The final figure has his back to us. He is slightly hunched and clearly lost in his own reflections. He has come there to be alone. All the figures 'appear to be silently awaiting for their respective times to return to home as they stand at the bar, engaging in little, if any, conversation. Each customer seems to be attempting to escape from the pain of the sad and lonely night'. ${ }^{31}$

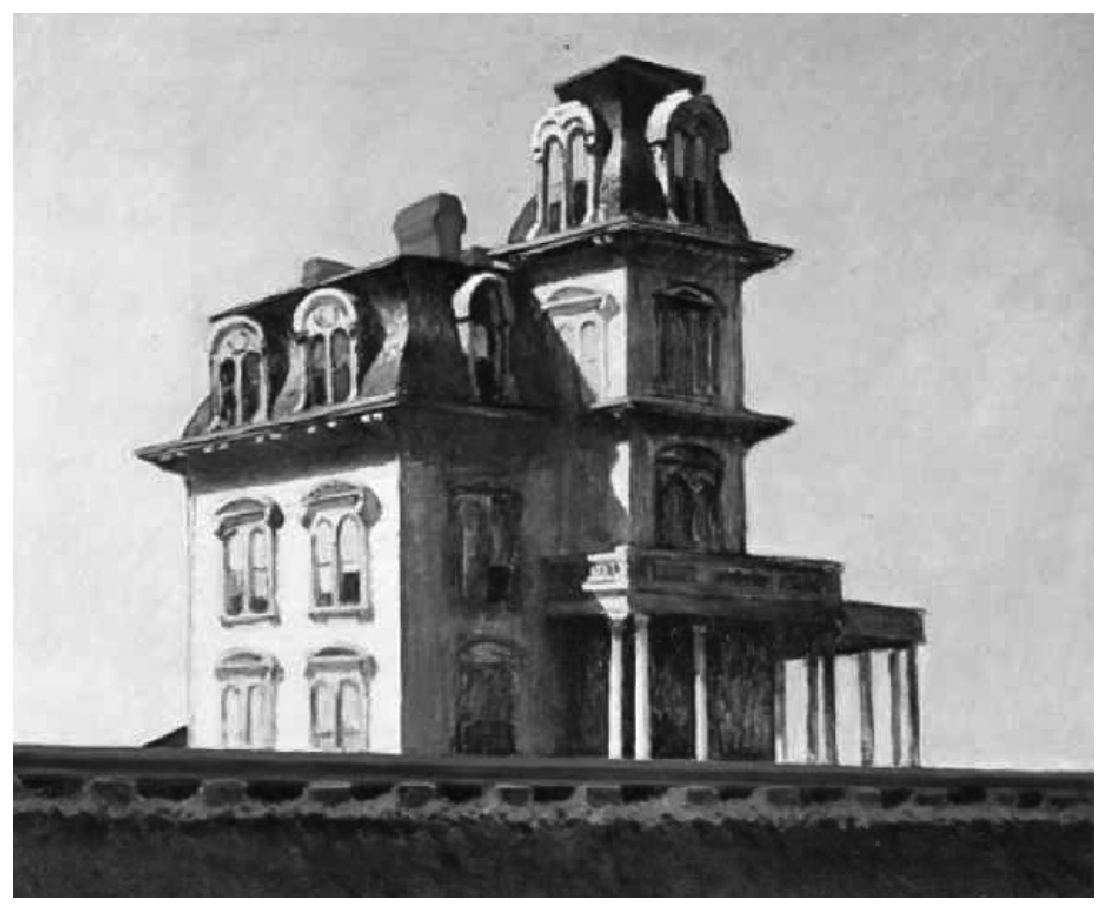

Architecture always formed a central part of Hopper's work. ${ }^{32}$ According to De Botton, "Hopper is the father of a whole school of art which finds as its subject matter "liminal" spaces, buildings that lie outside homes and offices, places of transit where we are aware of a particular kind of alienated poetry'.33 Hotel by the Railroad is a remarkable study of a house that evokes in us mixed feelings of empathy and foreboding. The house is totally alone, kept company

B Ungles 'Edward Hopper’. http://www.missouri.edu/ bkuc97/edhopper.html (Accessed 13 July 2006).

32 For an excellent look at post-apartheid legal architecture, see Le Roux (n 6 above).

33 De Botton (n 30 above) 3. 
only by the railroad, and we cannot but help feel sorry for it. Yet at the same time its stark lines and undeniable eeriness put us off balance and make us think twice before going up to give it a hug. The house seems 'more like a place to die than a place to live'. 34 But its solitude also emanates a certain strength - an unflinching conviction in itself, necessitated because there is nothing else but the occasional passing train to keep it company.

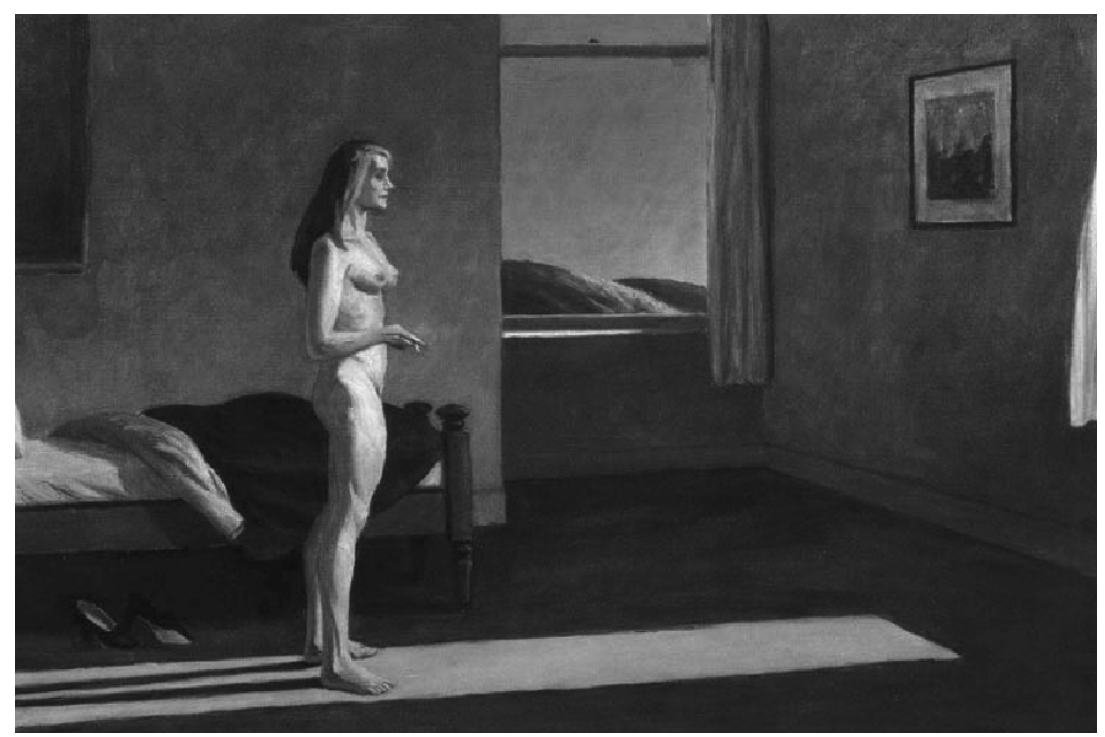

In Woman in the Sun a naked woman stands in a hotel room at sunrise staring out of the window. She has just climbed out of bed and is smoking a cigarette that she holds carelessly at her side. She is staring directly at the sun, lost in contemplation. She is not sad, but she is undoubtedly alone, remembering someone she has loved or lost, or contemplating some great obstacle that she has just overcome or will soon be facing. Basking in the sunlight, 'embedded in [her] existence, in [her] intimate knowledge of the solitude of the self'. 35

So accomplished was Hopper at his craft that he could induce the most basic feelings of emptiness and longing with nothing more than rays of light. Although the use of light was essential to all his paintings, $A$ room by the sea is unique in capturing an intense feeling of incompleteness, but also of hope, with nothing more than a door, a wall, a floor, the sea and a beam of light. The light only reaches 
partly into the room - much of the floor and wall are left in shadow. On the right side we see the vast expanse of the sea, while on the left is the shadowed echo of a living room. The whole room seems to want to burst out and become one with the sea, yet it is constrained and can only admire its beauty and unbridled splendour while it is drenched in the sun's light. Later, when the sun continues its journey westwards, the light will fade and the room will be left alone again, hearing the waves, but seeing nothing. For its part, the light is stretching to explore the whole room, but can only reach so far, forever constrained by the angle of the wall and confines of the door.

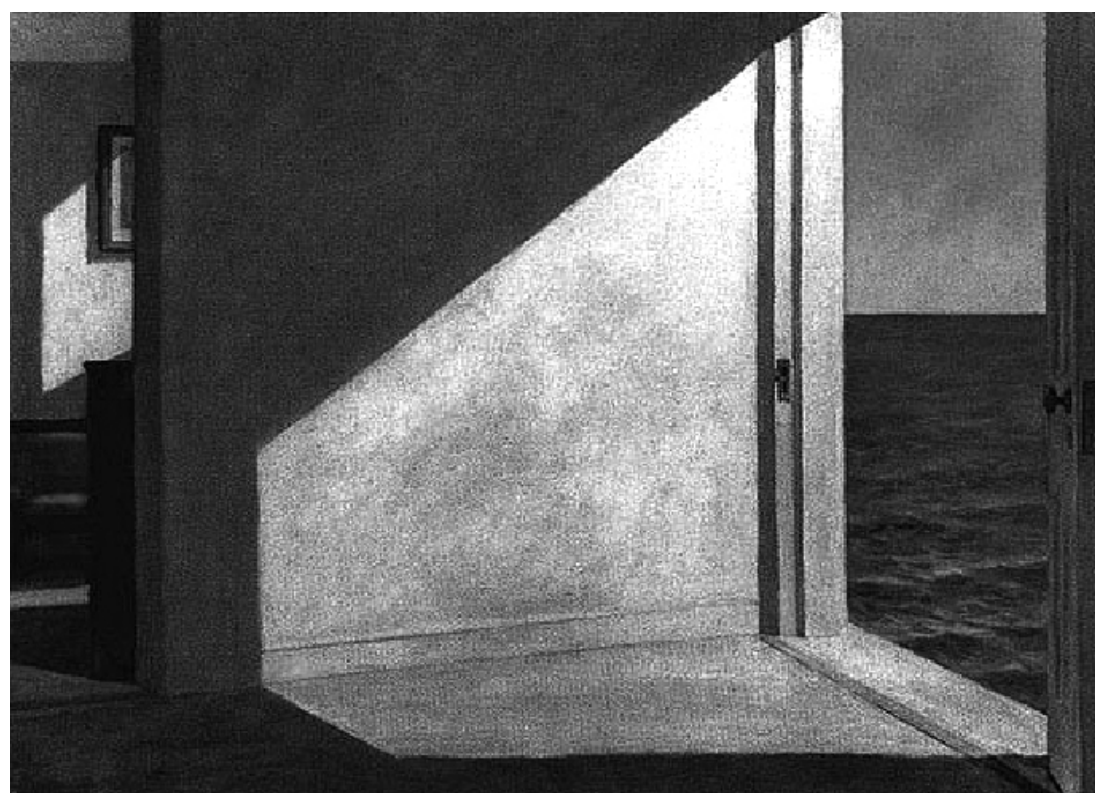

But there is much more to Hopper's paintings than loneliness. Hopper himself is quoted as saying that 'the loneliness thing is overdone'. ${ }^{36}$ A recent art critic agreed with him: ${ }^{37}$

there is far too much seminar talk about alienation, isolation, and psychic dislocation. Of course, they are an essential part of Hopper and America. But it is Hopper's rapturous joy in his melancholy that really commands interest - isolation and despair being otherwise rather common, modern and dull.

This embracing of sadness is exactly what De Botton finds so magnetic and consoling about Hopper's work. Strangely, it is the apparent 
bleakness of Hopper's paintings that allows them to inspire, rather than depress. 'Perhaps' De Botton reflects, '[this is] because [his paintings] allow viewers to witness an echo of their own griefs and disappointments, and thereby to feel less personally persecuted and beset by them. It is perhaps sad books that console us most when we are sad, and the pictures of lonely service stations that we should hang on our walls when there is no one to hold or love'. ${ }^{38}$ If De Botton is correct, and I believe he is, then every judge should have a Hopper painting on their wall.

Indeed, it is not difficult to imagine that any one of the figures in Hopper's paintings, the barman, the woman, the house, the room or even the light, is a judge who is burdened by the weight of their office. They are searching for the answer to a case, an answer they know they cannot justify. Indeed, the paintings tell a story.

After hearing a case, a judge leaves the court late at night and walks to an all-night diner. She orders a drink and enjoys the quiet and isolation. It allows her to think about the case, about what she must face before she comes to a decision. She is lonely and apprehensive, but determined ...

Next to the railroad, a judge is stuck deep in indecision, unable to find any solution she is lost in despair. Yet there is a 'poetry' in the despair as it is an indispensable part of the process that will lead her to his destination - decision. If we do not reach into the depths of our own depression, how can we properly acknowledge the sacrifice we demand of others?

A judge staring out of the window may, after a sleepless night, have finally reached a conclusion. The sunlight is purging her of all her doubts and giving her the resolve to stay the course while she continues to regret the sacrifice she must make ...

The sacrifice is made. The judge strains to fully acknowledge it. She reaches, stretches for that elusive trace of a trace at the heart of the heart. So close, coming together, but never complete, always absent. As it should be.

Perhaps it is possible, as the story suggests, that through lonely reflection alone a judge can come to acknowledge sacrifice, but as I will argue later, it is more likely (and more fun) that the judge's loneliness must be transformed into laughter to fully appreciate the depths of sacrifice. But the journey through loneliness remains a vital stage to reach our destination. 
If the [judge] ... must pass through hell, then she must affirm the price that the Dionysian poet has to pay - loneliness and madness. ${ }^{39}$

As a result of the comforting melancholy of Hopper's paintings, De Botton argues that ${ }^{40}$

[i]t's a curious feature of Hopper's work that though it seems concerned to show us places that are transient and unhomely, we may, in contact with it, feel as if we have been carried back to some important place in ourselves, a place of stillness and sadness, of seriousness and authenticity: it can help us to remember ourselves. How is it possible to forget 'oneself'? At stake is not a literal forgetting of practical data, rather a forgetting of those parts of ourselves with which a particular sense of integrity and well-being appears to be bound up. We have many different selves, not all of which feel equally like 'us', a division we confront most clearly in relation to our physical appearance, where we may judge that the person a photographer has captured, while something to do with the being bearing our name, in fact has very little connection with the spirit and attitude we would choose to identify with. This visual dynamic has a psychological equivalent, for within our minds too, we are made aware of constellations of ideas and moods distinct enough to feel different personalities - an inner fluidity which can on occasion lead us to declare, without any allusion to the supernatural, that we are not feeling as if we are ourselves.

This feeling of separation from 'ourselves' is a natural consequence of loneliness. But it also betrays a hint of madness. Loneliness always creates a separation from normality that causes our minds to work in different ways and our eyes to see things differently. The loneliness of the judge may also alter his perception of law. He might even lose it. $^{41}$

Have you not heard of the madman who lit a lantern in the bright morning hours and, like Diogenes searching for an upright man in the Agora, ran to the marketplace and cried: 'I seek Law! I seek Law!' Whither is Law? I shall tell you: we have killed him - you and I.

This journey through loneliness is necessitated by the dilemma of the unjustifiability of law and the need to acknowledge sacrifice and leads to the possibility of madness. It also leads us to Jacques Derrida. While Van der Walt is concerned about the unjustifiability of judicial decision making, Derrida, although following a similar line of thinking, requires more than mere acknowledgment to discover the traces of justice. He requires a madness. It is therefore vital that those who

39 A Gearey 'African Nietzsche: Poetry, philosophy and African legal thinking' (2003) 24 Cardozo Law Review 913.

40 De Botton (n 30 above) 4-5.

41 F Nietzsche The gay science (1974) at Book III para 125, as altered in J Yovel 'Gay science as law: An outline for a Nietzschean jurisprudence' (2003) 24 Cardozo Law Review 638 (the word 'God' has been replaced with the word 'Law'). 
enter his castle of deconstruction do so with a lonely and empty mind that can easily be unhinged.

But first, some clarity. Derrida argues that 'for a decision to be just and responsible, it must, in its proper moment, if there is one, be both regulated and without regulation, it must preserve the law and also destroy or suspend it enough to have to reinvent it in each case'. ${ }^{42}$ This contradiction means that all legal decisions (possibly all decisions!) are undecidable. A decision can never be fully regulated and unregulated, it always flows from a rule or establishes a new rule, never both fully and simultaneously. A decision can therefore never be 'presently just, fully just'. ${ }^{43}$ Decisions approach justice but never touch it. Indeed, the ghost of the undecidability never leaves, it haunts forever the 'decision' so that nobody 'will ever be able to assure and ensure that a decision as such has taken place'. 44

Coupled with this insight, Derrida insists, in the same vein as Van der Walt, that just decisions demand a gift in the true sense - 'a gift without exchange' - to fulfil the duty to the other and that such unanswerable justice, which is akin to deconstruction, is in itself a madness. ${ }^{45}$ Finally, Derrida acknowledges that justice as impossibility rests on the horizon, reclines in the 'not yet'. It is this very unattainability that defines justice. 'Yet' at the same time 'justice, however unrepresentable it remains, does not wait. It is that which must not wait. ${ }^{46}$ A just decision must be immediate and infinitely postponed - must at once embody and deny all that came before it must exist in the past, the present and the future all at once!

After trying to accept all these contradictions that are the hallmark of the 'justice is deconstruction' model (if one can speak of models and Derrida in the same breath) that Derrida advocates, it is easy to conclude, as he does, that ' $\mathrm{t}]$ he instant of decision is a madness ... that must rend time and defy dialectics. ${ }^{47}$ It is an instant in which not only rules disappear, but the instant between a rule and a non-rule vanishes into non-time so that there is only a cloud of uncertainty and undecidability. Yet out of this cloud must come a decision, must emerge justice. It seems that madness in decisionmaking is not only a consequence of the nature of Derridean justice, it is a prerequisite - the madness of the instant of the decision of justice lights the spark in the justice's ghost that emerges as a bolt of lightning from the cloud of unknowability!

J Derrida 'Force of law: The mystical foundations of authority' in Acts of Religion (2001) 251.

n 42 above, 253.

n 43 above.

n 42 above, 254.

n 42 above, 255.

n 46 above. 
Sounds good. But what does it mean? My difficulty with Derrida has always been fairly simple. I agree with him on a theoretical level. Justice 'is' the unattainable contradiction of rules, responsibilities and time - but how does that translate into a change in the current approach to judicial decision-making? Derrida (purposefully I am sure) offers no practical suggestions on how judges should approach their work to ensure more 'just' 'decisions'. I am sure Derrida would respond to any request for guidelines with a laugh and possibly a brief explanation that a practical guide to achieving justice in decisions would prevent justice in decisions. Justice cannot be learnt or taught or predicted, to think so is to deny the very essence of justice. The core of the decision is the denial of rules, the abandonment of direction, an embrace of insanity.

Surely the madness that Derrida talks about is not a literal requirement? Can it mean that in order to extract a just decision from the madness of decision, one must in fact be mad? Surely not? But maybe something similar?

I can hear Derrida's ghost laughing at me ...

\section{Laughter}

Perhaps I know best why it is man alone who laughs; he alone suffers so deeply that he had to invent laughter.

Friedrich Nietzsche

Laughter, especially when it is brought on by loneliness or depression, is the closest most of us will come to madness. As will become clearer later, laughter is, like madness, a suspension of reason. Perhaps the only difference is that laughter is more temporary than madness. But laughter is hardly associated with law or with judges. The law is a dignified, sombre and serious profession. What role can laughter play in the lofty hallways, dusty libraries and three-piece suits of the legal world? More than you would think.

Humour has for centuries been part of (at least the Anglo-Saxon) judicial tradition. It has not always been encouraged, but it has flourished nonetheless. However, before I begin with an examination of the place of judicial humour in the legal landscape, I would like to offer the reader a few prize extracts from the often dusty and boring pages of the law reports. The first example is a judge's response to a defendant's claim on the charge of sheep-stealing that the sheep killed itself by rubbing its neck against a sharp rock: 48

[T]hat is a very plausible suggestion to start with, but having commenced your line of defence on that ground, you must continue with 
it, and carry it to the finish. And to do this you must show that not only did this sheep commit suicide, but that it skinned itself and then buried its body, or what was left of it, after giving a portion to the prisoner to eat, in the prisoner's garden, and covered itself up in its own grave. I don't say the jury may not believe you; we shall see. Gentlemen, what do you say? Is the sheep or the prisoner guilty?

This next example is the full text (including footnotes) of Brown $v$ State: 49

The D. A. was ready

His case was red-hot.

Defendant was present,

His witness was not.

He prayed one day's delay

From His honor the judge.

But his plea was not granted

The Court would not budge. ${ }^{50}$

So the jury was empanelled

All twelve good and true

But without his main witness

What could the twelve do? ${ }^{51}$

The jury went out

To consider his case

And then they returned

The defendant to face.

'What verdict, Mr Foreman?'

The learned judge inquired.

'Guilty, your honor.'

On Brown's face-no smile.

'Stand up' said the judge,

Then quickly announced

'Seven years at hard labor'

Thus his sentence pronounced.

'This trial was not fair,'

The defendant then sobbed.

'With my main witness absent innovation and departure from normalcy in writing opinions; especially in the 51 copious use of footnotes.

This opinion is placed in rhyme because approximately one year ago, in Savannah at a very convivial celebration, the distinguished Judge Dunbar Harrison, Senior Judge of Chatham Superior Courts, arose and addressed those assembled, and demanded that if Judge Randall Evans Jr ever again was so presumptuous as to reverse one of his decisions, that the opinion be written in poetry. I readily admit I am unable to comply, because I am not a poet, and the language used, at best, is mere doggerel. I have done my best but my limited ability just did not permit the writing of a great poem. It was no easy task to write the opinion in rhyme. 
I've simply been robbed.'

'I want a new trial-

State has not fairly won.'

'New trial denied,'

Said Judge Dunbar Harrison.

'If you still say I'm wrong,'

The able judge did then say

'Why not appeal to Atlanta?

Let those Appeals Judges earn part of their pay.'

'I will appeal, sir' -

Which he proceeded to do-

'They can't treat me worse

Than I've been treated by you.'

So the case has reached us-

And now we must decide

Was the guilty verdict legal-

Or should we set it aside?

Justice and fairness

Must prevail at all times;

This is ably discussed

In a case without rhyme. ${ }^{52}$

The law of this State

Does guard every right

Of those charged with crime

Fairness always in sight.

To continue civil cases

The judge holds all aces.

But it's a different ball-game

In criminal cases. ${ }^{53}$

Was one day's delay

Too much to expect?

Could the State refuse it

With all due respect?

Did Justice applaud

Or shed bitter tears

When this news from Savannah

52 See Murphy $v$ State 132 Ga App 654-658, 209 SE2d 101, wherein a well-written and well-reasoned opinion discusses the reasons why a denial of motion to continue in a criminal case was erroneous and subject to reversal.

53 See Hobbs v State $8 \mathrm{Ga}$ App 53, 54, 68 SE 515, where it is demonstrated that a motion to continue in a criminal case must not be judged with the same meticulous severity as in civil cases. 
First fell on her ears?

We've considered this case

Through the night - through the day.

As Judge Harrison said,

'We must earn our poor pay.'

This case was once tried-

But should now be rehearsed

And tried one more time.

This case is reversed.

The next three examples are all short extracts from judgments by Judge Kozinski who has become somewhat infamous for his judicial wit. The first relates to a government informer while the last two speak for themselves.

Miller was a prostitute, heroin user and fugitive from Canadian justice; but otherwise she was okay. ${ }^{54}$

We answer unequivocally: yes and no. ${ }^{55}$

As a linguistic matter, 'and' and 'or' are not synonyms; indeed, they are more nearly antonyms. One need only start the day with a breakfast of ham or eggs to be duly impressed by the difference. ${ }^{56}$

There seems to be divided opinion about the appropriateness of humour in judicial decisions. On the one hand, there are those who regard judicial humour as 'an enfant terrible that, like any undisciplined child, amuses its inordinately tolerant judicial "parents" at the expense and dismay of the rest of society'.57 They argue that humour in judicial opinions is disrespectful to the litigants of the specific case and to society's perception of the law as a solemn and dignified institution. The important interests at play in any case demand that, '[h]owever amusing someone else's dispute may be, it is anything but funny to have one's own right to property, liberty, or, good reputation determined by a judge'. ${ }^{5}$ Marshall Rudolph (an unfortunate humour-impaired ${ }^{59}$ ex-student of Stanford University)

54 United States $v$ Simpson 927 F 2d 1088, 1089 9th Cir (1991).

United States $v$ Redondo-Lemos No 90-10430, slip op 1149, 1152 9th Cir (1992).

MacDonald v Pan Am World Airways Inc 859 F 2d 742, 746 9th Cir (1988) (Kozinski J dissenting).

Rudolph (n 48 above) 178.

n 48 above, 179.

For more on humour-impairment, see D Golden 'Humor, the law and Judge Kozinski's greatest hits' (1992) Brigham Young University Law Review 509 n 7. 
has gone so far as to suggest that the American Code of Judicial Conduct should be amended to include the following provision:

The use of humor in a judicial opinion is inappropriate if:

(a) a reasonable litigant would feel that he or she had been made the subject of amusement, or

(b) opinion utility would be compromised by the humor. ${ }^{60}$

In the other camp, some jurists see judicial humour as generally harmless and sometimes useful. Indeed, the best time for judges to stray from the traditional, solemn approach to legal writing is when they can 'subtly use wit or satire to articulate complex points of law'. ${ }^{61}$ In the slightly different context of legal journals, Knight has argued that a dash of humour would make generally tedious articles more bearable ${ }^{62} \ldots$ and prevent headaches. ${ }^{63}$

As I see it, there is indeed a place for judicial humour. The presence of humour in a judicial decision automatically calls into question the hallowed, unquestionable status of the law. It returns the law to earth and opens up in it more honest spaces for interpretation and dissent, but, more importantly, for enjoyment and laughter. I cannot improve on the following passage by Justice Sachs to explain what I mean: ${ }^{64}$

A society that takes itself too seriously risks bottling up its tensions and treating every example of irreverence as a threat to its existence. Humour is one of the great solvents of democracy. It permits the ambiguities and contradictions of public life to be articulated in nonviolent forms. It promotes diversity. It enables a multitude of discontents to be expressed in a myriad of spontaneous ways. It is an exilir of [judicial] health.

However, as the same Sachs J notes one paragraph earlier, 'laughter too has its context. It can be derisory and punitive, imposing indignity on the weak at the hands of the powerful'. ${ }^{65}$ Courts are indeed in a position of power and that position should not be abused to unnecessarily mock litigants for the personal amusement of judges. But at the same time, as will appear more fully below, humour is an

60 Rudolph (n 48 above). Seriously. Golden's response to this needs no addition. 'This is great! We endow our judges with power to adjudicate disputes involving life, liberty, and property. But we stop right there! We will tolerate no wit in an opinion. We cannot trust judges to use their discretion in anything so life and death as humor. And we will have absolutely no "compromised opinion utility" (whatever that is). We have standards!' Golden (n 59 above) 512.

61 Golden (n 59 above) 514. On the contrary, '[a] judicial opinion designed solely to invoke a laugh would be as substantively deficient as a poem about pig lard. Although the opinion would be memorable, it would have no impact on the law.' JT Knight 'Humour and the law' (1993) Wisconsin Law Review 900 n22.

63 n 62 above, 900 n 18.

64 Laugh It Off Promotions CC $\vee$ Sab International (Finance) Bv t/a Sabmark International (Freedom of Expression Institute as amicus curiae) 20061 SA 144 (CC) para 109.

65 n 64 above, para 108. 
indispensable tool in the search for justice. It is a fine line to tread that is best expressed by this passage by De Botton in an essay 'On comedy': 66

Rather than mocking us for our concern with status, the kindest comics tease us: they criticise us while implying that we remain essentially acceptable. Thanks to their skills, we acknowledge with an openhearted laugh bitter truths about ourselves that we might have recoiled from in anger or hurt had they been levelled at us in an ordinary, accusatory way.

As amusing and welcome as judicial humour is, humour has a decidedly more central part to play in law than brightening up unbearably dull law reports. In the hands of legal academics and legal practitioners (and hopefully judges!) humour is a tool to challenge and redefine the law by exposing, as incisively as possible, its shortcomings. That role is best illuminated by examining the work of Goodrich.

In his study of satire, Goodrich offers 'three theses' that describe the extent of the role that humour, and satire in particular, play in law. ${ }^{67}$ Before we move to address Goodrich's three theses directly, we must ascertain what precisely he means by 'satire'. Goodrich embarks on an extensive examination of the origin and historical development of satire from its Greek and Roman origins in religious theatre to it's inception in England and it's spread to the rest of the world. Satire has certain decidedly religious and moralistic roots that in the past operated to pull man-made law back to its God-made counterpart, 'to restore moral order ... and thereby draw the listener back from evil'. ${ }^{68}$ While it maintains many of its restorative and stabilising ancestry, the varied history of satire means that it has a 'slightly ambivalent definition' which is, considering its function, appropriate. Satire has always been bound to law in a symbiotic relationship, the one feeding off the other; the one cannot exist without the other. In the legal context, then, satire plays many roles: it challenges and attacks law, exposes the limits of law, and introduces an outside of law within the domain of legality and through all this supports and fosters the law. ${ }^{69}$ Ultimately perhaps, satire is about the questioning of power and the revelation of its vulnerability.

To return now to Goodrich's theses. We begin with the argument that 'all effective humour is satirical'. Law is characterised by solemnification - it is a place for reason, serenity and decorum from which all humour and levity must be expunged to maintain its

66 De Botton (n 30 above) 55.

67 P Goodrich 'Three theses on the unbearable lightness of legal critique' (2005) 17 Law and Literature 293.

$68 \mathrm{n} 67$ above, 297-298, quoting $\mathrm{G}$ de Conches Glosae in juvenalem satiras (circa 1135) 89.

69 Goodrich (n 67 above) 300. 
purity. ${ }^{70}$ This solemnity combined with the pervasiveness of law is precisely why humour, to be effective, must be satirical: ${ }^{71}$

All humor is satirical in that it is directed at something that is either individually or collectively laughed at so as to restore or subvert an order, practice, or norm. In either case, whether conserving or exploding convention, humor laughs at or laughs with and simultaneously at those outside the group, and external to the faith, the illicit, the illegitimate, the outlawed and outlandish. Whether good is bad or bad is good, humor threatens order and it is precisely the non-conformist use of humor, the exemplar of satire, that institutes the category of the unbound or of the outsider ... Levity and humor are alike denounced as discomposing order and confusing hierarchy. They are irrational because they refuse to recognise the solemnised site of rational worship.

In brief, humour is only funny if it subverts what we know and expect - the essence of satire. For de Botton recognising this nature of humour entails that ' $[\mathrm{t}]$ he underlying, unconscious aim of comics may be to bring about - through the adroit use of humour - a world in which there will be a few less things to laugh about. ${ }^{, 72}$

The next thesis states that all satire is juridicial. As Goodrich himself notes, this thesis flows easily from the first thesis and his historical exposition of satire. ${ }^{73}$ By challenging existing law, satire of necessity also asserts the primacy of an alternative 'higher' law or morality with which human law fails to comply: 'Satire engages most profoundly with divine law and with the law of nature because laughing at the extant order, ridiculing the hierarchy or institutions of government necessarily places the political order in question and implicitly challenges what medieval lawyers termed the beauty of rule. ${ }^{, 74}$ But satire is not a normative project - there will never be a law that it will not subvert. Satire is not beholden to any particular

n 67 above, 303-4. Goodrich later refers to law as resting on 'an attitude of faith, a sanctity prior to law, a hieros or holy space, a gap that founds the hierarchy of law and the descending order of norms' the challenging of which is the satirical task par excellence' (n 67 above, 309). This notion correlates with Derrida's ideas about the 'mystical foundations of authority'. According to Derrida, '[t]he authority of laws rests only on the credit that is granted them. One believes in it; that is their only foundation. This act of faith is not an ontological or rational foundation' (n 42 above, 340). What is important about this similarity is that if satire can challenge and expose Goodrich's 'holy space', it can do the same to Derrida's 'mystical foundation'.

Goodrich (n 67 above) 304-5.

De Botton (n 30 above) 56.

Goodrich (n 67 above) 306.

n 67 above, 307. Goodrich uses the imagery of the closet and clothes to describe how satire works. Satire is about looking into the closet or through the clothes to find the imperfect reality within (309-10). A satirist for Goodrich is 'someone, anyone who is willing to stare through the veil of social presence, solemnity and authority, at the closeted individual, the fragile body that subtends it' (311). The king, for example, exists as king only because of his crown and sceptre and the other signs that identify him as king. A judge is only a judge because of his robes (even if they are green!). The satirist looks past the external signs to see the person behind them. 
set of natural laws, but to the ideal of natural law that is forever unattainable. This idea of an unattainable natural law is not new Derridean justice and Douzinasian human rights ${ }^{75}$ are virtually indistinguishable. What Goodrich brings to the party is the link of the ideal to a method: satire.

The final leg of the argument is that 'all law is vulnerable to humour' which Goodrich bases on 'unpacking the verbal closet of law'.76 The fundamental indeterminacy of all language, including legal language, can easily be exploited by the satirist. The law is particularly vulnerable to this line of attack because it relies on words as the central part of its sacred ritual. By undermining the meaning of words, satire destabilises the sacred - removing the veil for all to see. ${ }^{77}$

And now we have stripped all the layers of the onion and we are at its centre. All the tears have been shed. We are nearing the end.

The interaction of humour and the law described above is important - humour in judicial decisions and satire in our approach to law are fantastic, exciting, radical goals. They will engender a more plural, more reactive law. More importantly, they make it possible for judges, and the whole legal fraternity, to laugh in and at the law. That is vital. But someone has yet to have the last laugh.

I described above the madness of decision that Derrida describes and those impossible contradictions that create that madness. I also suggested that laughter might offer a clue for judges to embrace (without suffocating) the madness that is the condition for justice. I do keep my promises. ${ }^{78}$

No laughter then without a crossing of boundaries, an implicit judgment, and an overturning of the norm. ${ }^{79}$

The satire and the humour described are the condition for laughter, but it is the laughter itself that is the trace of decision in our undecidability. Laughter has been described as an 'involuntary convulsion of the body' that has 'an imperious force of its own.' This force (dis)connects us not only from reason - for laughter is the very negation of reason - but from time and from the need for recognition.

75 See C Douzinas The end of human rights (2005).

76 Goodrich (n 67 above) 312.

77 This framework for the application of satire in law is not just a theory. Goodrich has also undertaken an extensive study into the practice of 'Satirical Legal Studies' (SLS) throughout history. He has identified a number of themes and schools of SLS, although the movement did not exist until he created it. $P$ Goodrich 'Satirical legal studies: From the legists to the lizard' (2004) 103 Michigan Law Review 397.

78 Although I am sometimes late.

79 Goodrich (n 67 above) 301-302. 
Laughter is not rational - cannot be rational - we can laugh only when reason departs, indeed that is the reason why we laugh. Laughing also transports us to a different time - a time of which is completely removed from where we were, because we were in reality, and laughter cannot exist in reality. There is no room for reality when we laugh, and no room for laughter when we are real. We become so completely consumed by laughter that everything stops. The world stops spinning. Our hearts stop beating. And we laugh. ${ }^{80}$ Normal time continues, but we are not a part of it. We must abandon and submit to the (dis)location, of reason of law of life of love of dreams of banana peels of three men sitting in a bar of a dead parrot, that caused our laughter before we can return to 'normal' time.

And in that laughing time and space there is no more impediment to giving uncontrollably, unreservedly 'without exchange, without circulation, without recognition or gratitude'. ${ }^{81}$ In the absence of reason and time the ghost of hospitality comes to visit. (If you were a ghost, would you not rather visit a laughing man than a crying one?) Derrida tells us that 'giving oneself in hospitality entails deciding to expose oneself and offering oneself, giving oneself, but this decision cannot remain mine, because if I master this decision I do not give anything' ${ }^{82}$ But that is the beauty of laughter - it is involuntary! We do not 'choose' to laugh - cannot choose. It is in laughter that the scent and the trace (the scent that is the reality, the trace that is the whole) of madness and of hospitality, of justice and of fullyacknowledged sacrifice reside. ${ }^{83}$

That is not to say that every decision made while laughing is just, nor that all a judge needs do is get his clerk to tell him knock-knock jokes while he works. Firstly, knock-knock jokes are not very funny. But even if they were, it is not laughter as a physical action but laughter as a mental attitude that judges should cultivate: laughter as a constant appreciation and creation of humour and satire. The opening up of all law and understandings of law to the full force of judicial wit and critical satire can only help to breed judges who take themselves and the law slightly less seriously. Judges must become complicit, no, active, in destroying the hallowed, unapproachable

The time of laughter is different to the 'time of reconciliation'. That time is 'marked by a Heideggerian "whiling" or lingering (verweilen) with fellow mortals' while the time of laughter is not one of waiting or of doing, but of being. J van der Walt 'The time of reconciliation' (2004) 19 South African Public Law 583.

81 Derrida (n 42 above) 254

82 J Derrida 'Accueil, Éthique, droit et politique' in Seffahi (ed) Manifeste pour l'hospitalité (1999) 152, as quoted and translated in J van der Walt 'The (im)possibility of two together when it matters' (2002) Journal for South African Law 475.

83 All these factors only apply 'within the laughter'. As Van der Walt writes: 'Outside the play of the political event singularity again gets displaced by unity' Van der Walt (n 80 above) 577. Laughter is a political event. 
corridors of the law. They must laugh them to the ground. Not because the problems of litigants or of legal principle are trivial or amusing, but simply because the only way a judge can truly, honestly take his job seriously, is not to.

\section{Conclusion}

I think the next best thing to solving a problem is finding some humour in it.

Frank A Clark

I honestly believe that an approach of judicial laughter can solve all the problems that I have arrayed against it. Laughter is nothing if not honest and can easily be candid about justification. Laughter can help to overcome the inevitable Hopperesque loneliness of judicial office and thereby lead them to the best manner of acknowledging sacrifice, through humour rather than depression. However, the loneliness of office cannot be avoided; it is a vital ingredient for judicial humour and a condition for justice through sacrifice. It is the absurdity and impossibility of a judge's position that should help him find something to laugh at. Finally, laughter creates the possibility for a "just madness' - a madness of decision-making in which all the contradictions of Derridean justice can be traced and retraced back to the madness of laughter.

But even if I am wrong - at least it was fun! 